\title{
Womens' views on men's art in Chambri, East Sepik Province, Papua New Guinea
}

Le regard des femmes sur l'art des hommes à Chambri, Province de l'est Sepik, Papouasie Nouvelle-Guinée

\section{Nicolas Garnier}

\section{(2) OpenEdition}

Journals

Electronic version

URL: http://journals.openedition.org/jso/8720

DOI: $10.4000 /$ jso. 8720

ISSN: $1760-7256$

\section{Publisher}

Société des océanistes

\section{Printed version}

Date of publication: 15 July 2018

Number of pages: $35-44$

ISBN: 978-2-85430-135-9

ISSN: 0300-953x

\section{Electronic reference}

Nicolas Garnier, « Womens' views on men's art in Chambri, East Sepik Province, Papua New Guinea », Journal de la Société des Océanistes [Online], 146 | 2018, Online since 15 July 2020, connection on 24 July 2020. URL : http://journals.openedition.org/jso/8720 ; DOI : https://doi.org/10.4000/jso.8720 


\section{Womens' views on men's art in Chambri, East Sepik Province, Papua New Guinea}

by

Nicolas GARNIER*

\begin{abstract}
In anthropological literature, secrecy is a central feature that opposes male and female in Sepik societies. Based on an analysis of women's perception of the men's house and the way they can occasionally enter it, this paper considers the way men's secrecy defines cross-gender relationship. Contemporary accounts and early anthropological description are compared to shed light on what women know about male secrets, about what they tend to hide from what they actually know on that matter. Three main arguments are developed to explain why women do not say anything about what they may know about men's secrets: shame for Mead, the fear of sorcery or the existence of a women's esoteric body of knowledge according to contemporary Chambri testimonies. While early observers tend to emphasize a profound dichotomy between male and female realms, recent observations made among the Chambri nuance this strict opposition.
\end{abstract}

KeYwords: Margaret Mead, Gregory Bateson, secrecy, men's house, Chambri

In Sepik societies, it seems easy to establish two distinctive types of artefacts: men's versus women's material productions. Whilst some literature focuses on production modes and opens innovative perspectives on gender roles in the production of artefacts (Kaufmann, 1972; Schindlbeck, 1980; Coupaye, 2013), other scholars have studied the role of artefacts in exchange systems and in social organisation (Mead, 1934; Bowden, 1983; Garnier, 2007). Finally some studies have delineated stylistic areas (Schefold, 1966; Newton, 1971).

\section{RÉSUMÉ}

Dans la littérature anthropologique, le secret est une notion centrale qui oppose les hommes et les fermmes dans les sociétés du Sepik. À partir de l'analyse de la perception que les fermmes ont des maisons des hommes et de la maniere dont elles peuvent y pénétrer, cette étude envisage la manière dont le secret des hommes définit les relations entre les hommes et les fermmes. Des témoignages contemporains et des descriptions anthropologiques précoces éclairent ce que les fermmes savent des secrets des hommes et de ce quielles tendent à cacher de ce quelles savent à ce sujet. Trois principaux arguments sont développés pour expliquer pourquoi les femmes sont mutiques à propos de ce quielles sauraient des secrets des hommes : la honte pour Mead, la peur de la sorcellerie ou l'existence d'un savoir ésotérique selon les témoignages contemporains des Chambri. Tandis que les premiers observateurs mettent l'accent sur la dichotomie entre les mondes des hommes et des femmes, des observations récentes faites à Chambri nuancent cette stricte opposition.

Mots-Clés : Margaret Mead, Gregory Bateson, secret, maison des hommes, Chambri

Most studies devoted to Sepik art have neglected the way women perceive men's production. Symmetrically, only a few studies mention the way men perceive women's production, apart from their alleged contempt, as quoted by Gregory Bateson about the Iatmul (1980: 149-150). This presentation analyses the little we know about women's perspective on Chambri men's houses. Though they are being built to hide men's secrets, they nevertheless remain visible to women's gaze. This paper will discuss what is shown, what

* Chargé de collections Océanie. Paris, musée du quai Branly-Jacques Chirac, mokumpandi@netcourrier.com. 


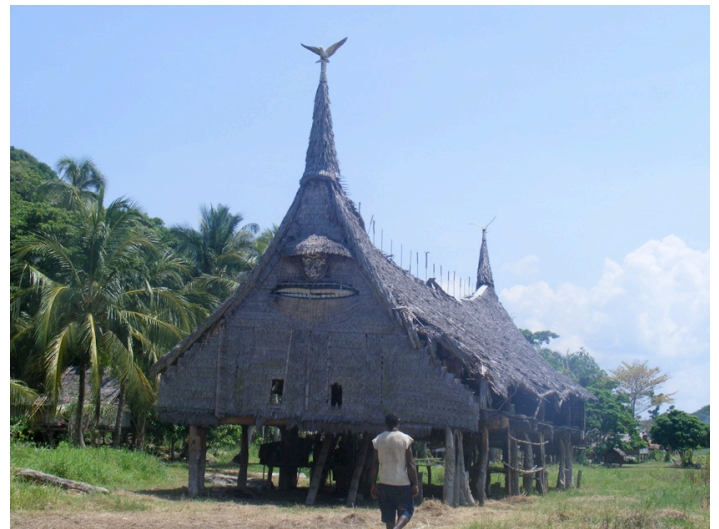

Рното 1. - View of the Holmimbit men's house, Kirimbit, 2005 (C) N. Garnier)

is seen, what is meant to be hidden, and what is actually known from what was supposedly not to be known. Women's view and knowledge about men's houses reveal to what extent they know about men's secrets. The level of women's knowledge about men's secrets blurs the presumed opposition between male and female realms.

Sepik men's houses are perhaps the most famous Gesamtkunstwerk from Melanesia. They combine the Sepik artistic achievements at their highest level of quality. They are pieces of architecture of extraordinary complexity. Many techniques such as sculpture, plaiting, bindings, stitching, painting, and flower arrangements give these works of art their spectacular features. Occasionally they become stages for dance and music performances whose elaboration equals the artistic ambition of its architecture. Men's houses have been both the object of scholarly research (Hauser-Schäublin, 1989; Garnier, 2007; Coiffier, 1994 among many others) and the topic of innumerable non-academic publications. In literature, Sepik men's houses are the utmost expression of men's culture and are opposed to the women's realm (including female activities, rituals, worldviews...). For most commentators, writing about men's houses signifies taking the point of view of men. As men's houses are their creations, as they shelter men's secrets and as they seemingly exclude women, it seems at first that only the men's point of view can be considered legitimate.

This paper draws on a previous article exploring the audience appreciation of a masked dance in Chambri (Garnier, 2015). In the domain of people's appreciation of visual artworks, one should pose a double question: what are women's understanding and appreciation of artworks, on the one hand, and on the other hand, what women know about men's secrecy and consequently womens' reactions towards its partial exposure. This paper

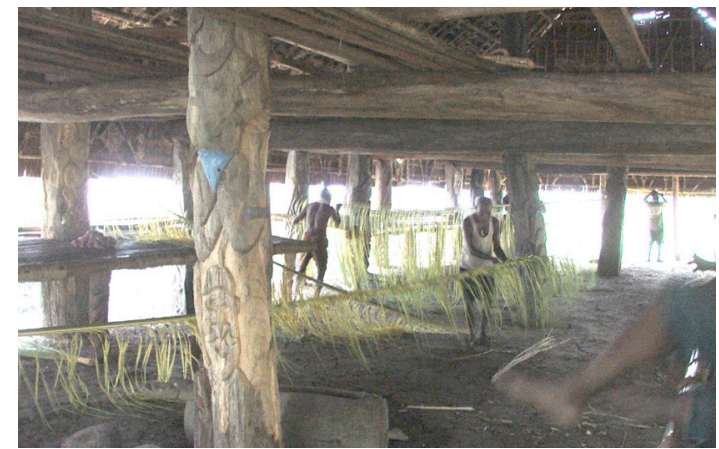

Рното 2. - Making of the sewas, literally the "skirt" of the men's house, that is used as a blind at the periphery of the structure, 2007 (C N. Garnier)

focuses on a particular men's artefact: men's houses (called irman in Chambri) that is supposed to symbolise women's exclusion from male politics and rituals. Today, the proportion and the size of the building, the complexity of the bindings attaching the various wooden structures together, the choice of the material, the style of the painted sculptures that cover the posts and the beams are the object of intense debates. They consider these buildings as an artistic achievement. It is also the visual focal point of the village skyline. Irmanpari (the plural of irman) emerge far above the other houses and of many trees; only the oldest coconuts that are planted in the vicinity dominate these spectacular pieces of architecture. While walking in Chambri, and in many Sepik villages, it is impossible to ignore their presence.

First, early testimonies on cross gender art appreciations (Mead and Bateson) will be compared with contemporary narratives from Chambri people. After starting work with the Chambri in 1997 I noticed that most things that are made by men (men's houses, tools, musical instruments, canoes, artefacts made for local use or for tourist trade) or by women (artefacts made of looped strings, skirts, baskets, and flower arrangements) are often discussed and need to conform to a set of qualities, such as visual beauty, respect of tradition, technical strength but also innovation and individual sensibility ${ }^{1}$. Foremost, visual creations, whether made by men or women, need to provoke excitement, surprise, fear, puzzlement or amusement.

Mens' houses embody many of the aesthetic qualities prised by the Chambri, meanwhile this amazing architectural envelope is considered by the Chambri as a fence that hides men's secrets. However we would like to question to which extent the preservation of male secrecy is efficient to delineate distinctive and independent male

1. I have been working with the Chambri since 1997. After spending several consecutive long fieldworks in 1997 and 1998 , I spent two years in the village between 2000 and 2002. Since then I established myself in Port Moresby at the University of Papua New Guinea. There many Chambri resided for months or sometimes years when they had matters to deal with in the capital city. Between 2003 and 2016 I returned to Chambri several times each year. 
and female realms. The last part of this paper draws on Tuzin's reflections on the contemporary challenges faced by Arapesh men that drive them to publicly unveil their male secrets.

My first argument is that an artefact made by a man is not only a man's concern and reciprocally, a woman's artefact is not only meant to concern women. A few years ago I demonstrated that string bags, women's artefacts by excellence, are highly regarded by men in Papua New Guinea (Garnier, 2009). They collect them, they parade with them, and they use them as signs of identity but also as a form of sexual attraction. For most men, these women's

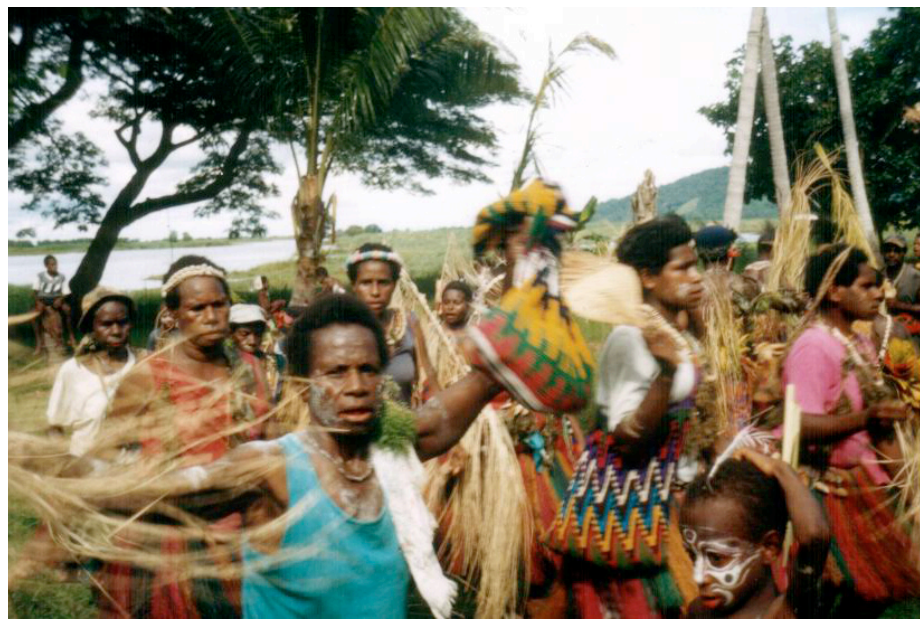

Рното 3. - Women dancing around the men's house Walindimi, 2008 (@ N. Garnier) artefacts generate profound emotions and men can be quite discursive about the aesthetic qualities they attribute to women's skills.

Early observers like Margaret Mead noted that men's houses were the object of aesthetic pride and that men dedicated much effort to their decoration. She also stated that women had no interest in art

"The women's interest in art is confined to sharing in the graceful pattern of social relations, a small amount of painting on her baskets and plaited cowls, and chorus dancing." (Mead, 1968 [1935]: 231)

Although Margaret Mead did not define what the concept of art meant for the Chambri, her text referred to the making of masks, sculpture, painting, music and the practice of dance. For her, art is a man's concern (she even argued that it is their main concern):

"The Tchambuli may be said to live principally for art. Every man is an artist and most men are skilled not in some art alone, but in many." (Mead, 1968: 230)

"[or for men, art] is the only important matter in life." (Mead, 1968: 230)

She placed women's boldness in opposition to men's sophisticated visual realm. In her often caricatured depiction of the Chambri, she linked the male artistic infatuation to frivolity and women's lack of artistic appetite with productivity and sincerity. At the same time, Gregory Bateson offered an almost identical stereotyped view on Iatmul men and women's aesthetic emotions. For him, men permanently express contempt for women's artistic achievements (Bateson, 1980: 149-150).

In early literature, it seems that men's houses are made for men and because of the relative distance imposed on women, these edifices are meant to be seen and admired by men only. Mead also noted that women had to walk away from these constructions. In reality women can approach men's houses ${ }^{2}$ and talk about them, at least episodically. She nevertheless argued:

"In Tchambuli, the tamberans are supposed to be only for the men and women play the part of distant spectators who carefully avoid referring in public to the fact that they know all about the Tambaran events." (Mead, 1934: 248)

I will narrate a complex game of deception and concealment in which men and women reveal and hide their views and emotions, and their knowledge of the opposite sex's views and emotions. The cult of secrecy that characterises Sepik River societies is only one side of my exposé. The culture of secrecy that is nodal in the way men's houses entail a relationship between men and women in Sepik societies, needs to be understood in close connection with the way women appreciate men's artistic achievements.

\section{Secrecy}

There is an abundant literature on the topic of secrecy in Melanesia, and especially things, narratives or events that need to be hidden from the opposite sex or from non-initiates (Allen, 1967; Hogbin, 1970; Herdt, 1982, 2003; Silverman, 2001; Tuzin, 1980; 1997; Hauser-Schäublin, 2011). Secrecy can be defined as "a compact between persons" (Herdt, 2003: XII) or as "an epic project of gender politics" (Herdt, 2003: Xv). In literature about secrets in Melanesia, secrecy delineates two groups of people, those who know about the secret, and those who cannot access it. 
It generally defines two types of ensembles: initiates vs. non-initiates and men vs. women. It is also understood that those who hold secrecy (secret knowledge, secret names, or secret artefacts) are in a position of domination over those who are excluded from the secrecy (Errington and Gewertz, 1987). Thus the secret that is protected is less important than the mechanisms that enable the division between two groups and the supposed domination of one group upon another. However, as Hauser-Schäublin noted (2011), in Sepik societies, secrecy plays often on an interwoven sequence of revelation and concealment. Her paper draws on the examples of the Abelam string bag which loose loops hide and reveal at the same time and of the men's house painted façade which complex patterns partly disclose outside ("give a glimpse") the secrecy of the successive stages of male initiations. Henceforth Abelam secrets are never completely protected, and in the manner of the twisted loops of the string bags, they are simultaneously hidden and displayed. In contrast, Chambri men's houses seem to be a much more opaque protection, although women are occasionally able to access what is to be hidden. In Chambri, is men's house secrecy about a strict opposition men and women; is it about the first dominating the second? Could secrecy be defined as an action consisting of deliberately hiding something that is coveted by those from whom it is hidden? To return to Margaret Mead, who was the first anthropologist to testify about men's secrets in Chambri, she announced that Chambri women seem to know a lot about men's secrets.

"The elaborate ceremonies, the beating of water drums, the blowing of flutes, are no secrets from the women [...] We [women] don't say we know for fear the men would be ashamed. ${ }^{3 \prime}$

\section{Later Mead quoted a man's answer:}

"Yes, they know them, but they are good. Also - we might become so ashamed that we would beat them." (Mead, 1968: 246)

Margaret Mead concluded that the denial of knowledge reflects men's minor social position. Men's secrets are a women's concession that would enable men to pretend to owning social leadership while women are actually the rulers. This explanation is to be nuanced. Mead's description of the Chambri sex roles is intended to oppose point by point a popular stereotype of gender roles in American society. In order to paint the
Chambri so they oppose the Americans, she selected observations taken out from a larger series in which some obviously contradict those she decided to publish. To sharply oppose stereotyped views on American gender roles, Mead produced a symmetrical stereotyped portrait of the Chambri. Lastly, Mead incidentally referred to men's shame without further describing an emotional state that could justify men's secrecy and women's knowledge. She further claimed that both men and women pretended not to know in order to avoid embarrassing the opposite sex:

"Perhaps it is because the secrecy is so much a matter of form and courtesy between the sexes, instead of being the pivot upon which health and growth are set, as among the Arapesh, or a matter of family pride and disciplining the refractory, as among the Mundugumor, that the Tchambuli have been able to conserve so many different art styles, many of them undoubtedly inspired originally by far distant tribes and imported at some remote period either as tamberans or tumbuans." (Mead, 1934: 246)

In this last text, Mead considers that in Chambri the preservation of secrecy is not fundamental and could even be viewed as a cosmetic quality attributed to cross gender relationships. Then she argued that reciprocal deception gives birth to multiple art styles. Errington and Gewertz (1987) offered the first critical analysis of Mead's understanding of male and female relationships. For them men and women pursue distinctive goals. On the one hand men compete for the acquisition and preservation of a stock of secret names, while women, on the other hand, aspire to maintain a relative equality among themselves. For Mead and Errington and Gewertz, secrecy is central to Chambri society. For Mead, secrecy (hiding the men's realm named tamberan) is an instrument set up by men to establish domination over women. However men fail to impose their domination as women monopolise the economy. In opposition, Errington and Gewertz consider that secrecy resides in the possession of a stock of names that cannot be divulged, and that the possession of these secret names triggers men's competition to achieve prestige within their clans, and between clans. Thus women are not concerned with men's secrets, as secrecy only operates within men. Women play in another arena and their main preoccupation is to maintain equality amongst women while men act, on the opposite, to increase inequality among men.

Since the mid 1990's, when I started working with the Chambri, Chambri men confirmed

3. This quote made by Mead, has always surprised me, as today no women ever talks so casually of men's secrets. In my presence, I have never heard any women talking about what is hidden in men's houses. I cannot quote any women talking about men's activities in men's houses, or about initiation. I would never ask a woman or encourage a discussion on such matters. However, women can talk relatively openly about other types of secrets, such as about the identity of the dancers covered by large masks such as the Saki nemenen or the Meombank. However, men would not blame women for knowing the "hidden" identity of dancers. 
some of Margaret Mead's statements (except that women's exclusion is beneficial to artistic eclecticism), but brought new information that enable us to understand something about men's shame. Chambri people use the concept of shame (urenabas) to characterise relationships between individuals or groups of individuals.

\section{"Urnebas erub uren noramp, mundamar ingeub abu- siran: Men are ashamed because the women looked at them." (Gorden Pambang, 20 October 2015)}

This informant also claimed that it would be the same for the opposite sex. In other words, observing someone from the opposite sex creates a sentiment of some kind of suspicion that can be translated as shame. For contemporary Chambri, the sentiment of shame is generated by the gaze of the opposite sex rather by the discovery of something hidden. Two other explanations were given. Women know about men's secrets, but they express their knowledge on certain conditions. When interviewed in presence of men, Chambri women always denied very strongly knowing anything. In their denial, they explain that such kinds of topics are not appropriate for debate:

"Papa sabu pambresik, sumbui" (We cannot say anything about that, it is forbidden.) (Conversation with Chambri women from Kirimbit and Indingai, Rainbow area in Port Moresby)

For some Chambri men, they pretend not to know through fear of sorcery. For Matthew Tumangawi who is an elder from Indingai village, one the three villages established on Chambri Island:

"Actually elderly women [or women of higher status, big meri was the term in Tok Pisin used by Tumangawi, upwan nemenen my translation in Chambri] know about our secrets, about the secrets of the men's house. They know but they don't talk about that. It is forbidden. They only talk about these secrets to only few other women. This knowledge is transmitted this way. When a woman is about to die she transmits what she knows to a younger woman so her knowledge won't be lost. It becomes the secret of the women. But they cannot say that publicly [mundamar papa yireup pambresepran]. This is forbidden, this is a law." (Matthew Tumangawi, October 2015)

Matthew Tumangawi's testimony is interesting not because it states the impossibility of speaking about men's secrets in public, but because it reveals a women's form of secret knowledge that parallels men's secret knowledge. Men's realm is progressively revealed to young men in ritualised circumstances mostly during masked dances, sai (musical training) and initiations. Tumangawi supposes that women proceed the same way and that they ritualise a process of knowledge transmission from elders to juniors. Henri Maliwan equally admits that women know a lot about men's secrets but they cannot tell through fear of sorcery. He says that:

"Women don't approach men's houses and don't tell about men secret rituals by fear of sorcery [poisin in Tok Pisin, kapeur in Chambri, my translation.]" (Matthew Tumangawi, June 2013)

Henri Maliwan's argument does not oppose Tumangawi's hypothesis but rather complements it. It explains the sanction inflicted on those who breach the rules. It also questions Mead's assumption about beating wives. It can be argued that eighty years separate these various testimonies and that the sanction imposed on women could have evolved through time. However the justifications for women's silence about men's secrets are very different in nature. For Mead, women do not talk because that would make men ashamed, while for contemporary Chambri people, it is because it is the law and because this knowledge obeys a distinctive mode of transmission (Tumangawi and Chambri women) or because they risk death by sorcery (Maliwan). These Chambri accounts almost paraphrase a comment made by Tuzin about the Ilahita Arapesh men's secrets (Tambaran):

"Are women truly hoodwinked as the men think they are, or are they diplomatically concealing their scepticism? As discussed in the present chapter the fear that they will be killed for their doubts prevents women from responding candidly to such a question." (Tuzin, 1980: 263)

The three main arguments that explain women's silence about men's secrets were: shame, for Mead, kapeur (sorcery) for Henri Maliwan, a women's own system of knowledge parallel to men's systems for Tumangawi. However, each argument, taken separately cannot fully explain why men and women hide what they know, and why both sexes act as if the opposite sex did not know what they know.

Altogether the combination of the three arguments may explain the reciprocal denial expressed by men and women regarding men's secrets. During my many stays, women have always been very reluctant to talk about men's secrets, even if men were not present and even if they were guaranteed that their conversation would remain confidential. Most of the women that I have known for about twenty years showed a real embarrassment about answering these types of questions. In Chambri, it is common knowledge that women talking about men's secrets were to be killed ${ }^{4}$.

4. I heard this statement many times, although the way "guilty" women should be killed is not always specified. I do not know if Henri Maliwan's statement about women being killed by sorcery could be widely accepted in Chambri. 
Men know that talking to women about men's secrets would condemn the women to death. Mead only said "beating", but in my presence, men talked about killing women. To my knowledge such death has never occurred. However I heard stories about women who were killed because they breached other men's rules such as trespassing men's reserved space. While I cannot remember any case of Chambri men talking to other men about protecting their secrets from women, I was told on numerous occasions that I had to be very careful not to report some of our conversations in presence of women. "What belongs to the men's house needs to remain in the men's house" is an expression that could summarise these statements. In this regard the obligation of secrecy is equally shared by men and women. However, despite death threats, women know.

Margaret Mead described women who looked quite amused by men's secrets. I cannot remember witnessing such casual attitude in Chambri. Women's seriousness and minimalistic answers regarding men's secrets should not be over-interpreted but do not contradict Tumangawi and Henri Maliwan's views. They do not tell because they may fear men's reactions or because as a man, I was the least acceptable interlocutor to hear about women's knowledge.

\section{Visibility of men's secrets}

Before proposing a fourth hypothesis (after shame, sorcery and women's parallel knowledge), I would like to question what the secrecy of men's realm is. One needs first to distinguish the secrecy of men's realm from men's esoteric knowledge, as defined by Wassmann for example (2001). I am not here referring to the system that underlies and relates the thousands of names, the mythological tracks and spaces that enables Nyaura men (Wassmann, 2001) or Chambri men (Gewertz, 1977; Errington and Gewertz, 1987) to gain higher status. There are things that are meant to remain unknown to women, such as what is happening behind the initiation enclosure, what is inside the men's house, what are the musical instruments hidden inside the men's house, who are dancing in the masks... These multiple aspects are to remain secret however in Chambri there is no specific term that means secret. Manken numbun is an expression that can be translated as something hidden (and that can be something very casual, on the occasion of a game for example), something stolen and that needs to be hidden so the thief won't be caught, and finally something secret. Actually Chambri people do not use the expression Manken numbun to talk about men's secrets. They use instead a pair of expressions noramp umbrar and mundamar umbrar. Noramp and mundamar are among the rare nouns that are invariable (they are extremely few in Chambri). The first refers to a collective of men, while the second, to a collective of women. They are used in daily language to refer to a group of men performing something together (hunting, walking, discussing...) or being together in a particular place (on the lake, the mountain at the irman...). Mundamar is the symmetrical word that refers to women and that is used to talk about their collective activities (fishing, plaiting baskets, joking, dancing around the irman...). Umbrar is a possessive adjective plural that can be translated as "their" or "theirs". Therefore noramp umbrar can be translated as "[that] belong to men" or "men's realm". The expressions noramp umbrar and mundamar umbrar give shape to respective and distinctive domains of social life. Both oppose to a state of non-differentiation expressed by the pronoun numbrar alone ("their" or "theirs") or ibeunar ("our" or "ours"). These two pronouns cover collective realms where men and women are not differentiated. Those first expressions highlight distinctiveness rather than protection or invisibility. Noticeably the verbal form surkusak that describes a state of invisibility or hiddenness is not used in this context. This does not mean that secret things, rituals and forms of knowledge such as magic, genealogies, or sets of secret names that need to remain hidden, do not exist in Chambri. Magical practices are performed in great isolation and people use the verb surkusak in this context for example.

Thus the secret about the presence of real men in the masks, the secret about the content of the men's house and the secret about the origin of musical sound is difficult to preserve. In Chambri the invisibility of men's secrets is temporary and occasional. Many of these items are visible, often not in detail but at least from a distance and occasionally. Therefore men's secrecy is a transient state and cannot be considered as a permanent characteristic of men's houses. Consequently in Chambri secrecy consists in two intertwined operations: hiding something (names, dancers, musical instruments, the inner part of the men's house) and delineating a collective of individuals (men, women, initiates, non-initiates).

When considering men's house as a boundary that hides men's secrets and that brings together a collective of men, we realise that this enclosure is partly permeable. Chambri women can see or enter the inner part of the men's houses at least on three occasions:

- During initiation (bandi). In Chambri, as well as in some other Sepik societies, some women are initiated alongside men. In Chambri women have not been invited to an initiation since the 1980's although these rituals are still practiced on a regular basis. However, several Chambri women, particularly in Indingai, the central village, have their body covered with scars. In In- 
dingai people consider that women and men can be initiated regardless of their gender. Women undergo all the stages of the ritual, including the exposition of the sacred clan artefacts (kupunda). - A ritual in which women bake sago pancakes prior the opening of a men's house. I recently learnt about a ritual where women can enter the men's house. This ritual seems to have been reintroduced on the occasion of the completion of the reconstruction of Walindimi. It consists in inviting women from the clan who took part in the construction of the men's house to bake one sago pancake inside the men's house just before the opening. The ritual is supposed to precede the last set up before the official completion; the installation of two large carved birds (usanasim) on the lateral poles of the roof of the men's house.

- Lastly during several Catholic celebrations. In 2004 about fifty Chambri made a one week stay in the neighbouring mountain of Timbun, where hundreds of other Christians gathered. They stayed there to take part in a religious event called a Charismatic rally. A rally is a Christian gathering (many Christian denominations organise such events) that brings hundreds of devotees to pray for a few days. When the Chambri delegation returned, it was greeted by relatives (male and female altogether) in Walindimi, the largest of Chambri men's houses. It is tempting to view women's entrance into the men's house as deliberate repudiation of traditional order provoked by Pentecostal inspired forms of Christianity. If we project Tuzin's analysis of the revivalist ambition to the Chambri women, Charismatic rallies consist of reversing the traditional order and giving prominence to women. Recent literature on the Sepik (Telban, 2009, 2013; Falck, 2016) confirms the incidence of these new forms of Christianity on radical changes and cosmological revolution. Some Chambri men then justified this unusual ritual in saying that for very important occasions, women can enter men's houses. What they meant by "very important occasion" remains unclear. Thus, the unusual women penetration into the men's realm was perceived by (at least some) Chambri as a cultural continuity, and from what I observed, not a challenge or a rejection of an ancestral cosmology.

Today Chambri people argue that they first encountered Christianity in the 1920's and had their first church built in the early 1950's. Then, a special ground was allocated to the Catholic Mission in the centre of the village. At the same time, the Chambri seem to have overturned part of their traditions: they sold many of their most sacred artefacts to the missionaries and threw their sacred stones into the lake. These past events however relate to similar experiences described by Tuzin,
Telban and Falk, although some Chambri insisted that the 2004 event made no offense to traditional order. However, I remember that in the following days many women who attended the rally stopped performing their traditional duties (fishing, preparing food and taking care of children). They argued that the day of wrath was about to come and that it was important to get detached from mundane practices. In retaliation, they were severely beaten by their husbands. Therefore women's entrance into the men's house could have been a failed attempt to reverse the traditional cosmological order. To preserve the authority of traditional religion, men have given reasons to transform a political and cosmological unrest into a traditional practice. It is not excluded that women could enter men's houses on several occasions before colonial time. A few Chambri mythological accounts describe cases of women entering men's houses.

These three events demonstrate without ambiguity that women, at least those who were initiated, can enter men's houses and are able to observe and memorise their internal organisation, the details of the carved posts, and the presence of instruments of music (slit drums and flutes, and for some even the bullroarers). The last instance, the Christian ceremony obviously reflects recent inflections to Chambri culture. However, I was told on several occasions that women's intrusion into the men's realm happened in the past in certain (unspecified) circumstances. Perhaps war raids or long distance trade agreements might fall into this category?

Lastly the architecture of men's houses is often transparent and a large part of what is to be hidden is actually perfectly visible. Mead argued that there were fifteen irmanpori in Chambri during her visit, an assumption that is today confirmed by the Chambri. Although women cannot approach the buildings in construction, and although the construction sites are sometimes protected with a fence, it is very easy to observe their distinctive features. The monumental size of men's houses, their ornaments that are meant to be seen from distance (as often emphasized by elder artists) makes it difficult to hide them from the gaze of non-initiates. Furthermore, women's pathway (manaman ao, lit. the higher pathway) located a little higher than the lower ceremonial ground makes it the utterly perfect point of view to watch the details and the structure of men's houses. When men's houses are under construction or rotting apart, the inner part of these constructions becomes visible to everyone. Then nothing hides what is considered very secret by men: the inner part of the men's house and what happens inside ${ }^{5}$. Even fences that may have been built in the past around irman under construction cannot hide much especially if one considers that Chambri is a mountain and women usually walk on footpaths overlooking the area where irman are built. Therefore

5. Sacred paraphernalia and flutes are hidden away while the inner structure of the building is visible. 
men's realm as expressed by men's houses cannot be understood as a protected secret but rather as a delineated space that claims its distinctiveness from the public and women's realm.

\section{Modernity and the weakening of men's secrecy}

The seminal work of Donald Tuzin sheds new light on the disappearance of secrecy and the removal of men's rituals amongst the Ilahita Arapesh (The Cassowary's Revenge). Similarly Telban (2009, 2013) and Falck (2016) have demonstrated that Pentecostal forms of Christianity provoked spectacular and dramatic cultural shifts in Sepik societies. It is likely that dramatic changes occurred in Chambri, especially after ww II when the first large Catholic church was erected. At the same time, massive destructions of sacred artefacts and spectacular forms of Cargo Cults are reported by Chambri people. Today they rather emphasize a softer blend of local tradition and Christianity. Christianity and modernity (the first being a component of the second) are said to have brought necessary evolution, but no radical changes (Garnier, 2013). In consequence the values of the past are partly fading away. When I read accounts given to me in the 1990's describing the former behaviour in men's houses they bluntly contrast with what can be observed in some of the men's houses more recently. When I first came to Chambri, it was strictly forbidden to wear caps and foremost to bring transistors inside the men's houses. It is now common practice, particularly since most Chambri people can buy mobile phones, most of them being equipped with radios. It is now common to hear several radios playing together in the men's houses, including in the largest where one can expect to find elders (tabanum awinamp), elderly people being considered the guardians of traditions. Most young men admit that their changing attitudes profoundly irritate elderly men, but they do not change their behaviour. In many respects, attitudes towards men's houses are changing. However, one can legitimately ask if the introduction of modern patterns (radios, caps) have an impact on secrecy. In modern PNG radios and caps are very distinctive signs of masculinity, and one could argue that the behavioural changes that affect men's house do not necessarily symbolise a modification of gender relationships. Oppositely some changes can be considered as very pragmatic adaptations to external influences aimed at reformulating gender segregations in modern terms.

\section{Disclosing of men's secret and women's indifference}

In 1997 Donald Tuzin published the most detailed account on the effect of Melanesian Christianity on the disclosure of men's secrets. In 1985, a group of revivalist men disclosed men secrets during a Christian office. Tuzin highlighted a point of great importance: men's desire to protect their secret is not a response to women's curiosity, but rather a response to the belief that men have about women's curiosity. He noted that men's disclosure of their secret was greeted with some indifference by women:

"It is just that they did not particularly care. [...], mostly they were not impressed [by men's rituals excluding women]." (Tuzin, 1997: 161)

Similarly Silverman highlighted that men's secrets are judged inconsequent and even funny by women (Silverman, 2001: 167-168) as if finally masculinity was a concern for men but not really for women.

It is possible that the lack of conviction expressed by women, and the less defensive attitude of men towards their own secrets could be the result of slow cultural shifts. Many Chambri people argue that the slow decline of tradition and the progressive abandoning of rituals are due to people's new priorities. In Chambri many men are not interested in building men's houses or performing dances anymore. Money, new social status offered by the modern administration (village court magistrates, councillors, or ward members) becomes more valuable and command greater respect than the practice of ancestral rituals. In other words the feminine indifference coined by Tuzin and Silverman may also echo men's indifference.

But indifference is also contagious and pertains to Chambri aesthetics as a whole. If we give credit to Mead's argument about the central position of art and art production in the Chambri men's realm, the possible growing indifference demonstrated by some Chambri men and women may also be the result of recent changes. By recent changes, I mean a shift in visual expectations that has already been described by Gewertz and Errington about modern music (1991). However, it is likely that women's alleged indifference towards men's architecture relates to the Chambri concepts of two gendered separated realms. Noramp umbrar is not a concern for women and symmetrically mundamar umbrar is of no interest for men. Bateson made a clear statement about men's reluctance to take part in what is conceived as women's realm:

"These dances [women dances] are very resented by men who regard them with contempt and do all they can to discourage them. [...] For in spite of their contemptuous attitude, the men withdraw quietly enough when the dance is actually about to take place." (Bateson, 1980 [1958]: 149)

\section{Conclusion}

Tuzin pointed out that many men's secrets remain secret because of women's indifference. Men's 
stress on keeping specific knowledge or things secret from women as well as the desire of women to inquire about them both may have been overestimated, allegedly by Sepik men as much as by the anthropologists they were talking to (such as Mead for example). In other words, it is likely that women do not really bother about men's secrets and particularly the "most secret" or the core secrets as Tuzin puts it (Tuzin, 1997: 9). I just wonder if the concept of core secret may apply in Chambri as I already doubt that the term secret may be of relevance, at least in Chambri's case. What is hidden never remains totally and permanently concealed, as we have seen from the example of the irman whose architecture,

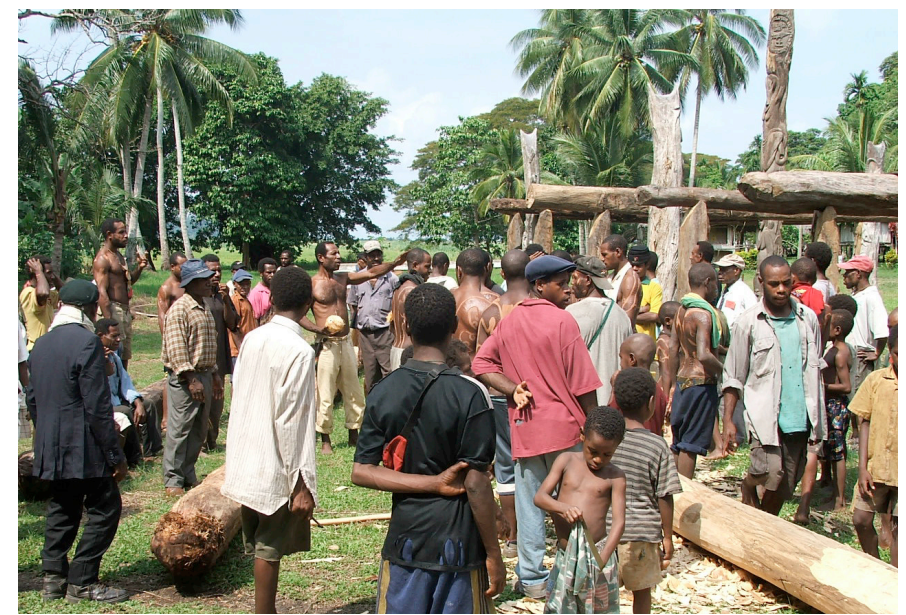

Рното 4. - Stage of the construction of Walindimi men's house, Wombun, 2006 (@ N. Garnier) and especially inner (therefore secret) architecture, is often visible (during construction or decay, or on special occasions whether they relate to ancient traditions or contemporary context). The example of the men's house offers an intriguing perspective from which to analyse reciprocal points of view of men and women on men's artefacts. I believe that men's concern for the protection of their secret may not be that these secrets will cease to be effective if shared with women, as implied by Mead, and Tuzin. For Mead and Tuzin, tamberan is a word that is synonymous to men's secrets. For them, tamberan (or men secrecy) defines masculinity. However it is doubtful that secrecy plays such a role in Chambri, where men and women share a large body of secret knowledge. The men's house may rather be an architectural delineation reflecting gender opposition in which men's enclosed space (noramp umbrar) breaks apart from public space. Public space includes women's realm and a wide space in which men and women interact. The men's house as a fence and an enclosure, does not create a secret nor a Tamberan. This opaque piece of architecture enables men (and initiated women) to delineate a space where their status can be temporary opposed to an undifferentiated realm. Male secrecy is not as argued by Mead a vain attempt made by men to demonstrate their domination over women. It is probably not a preserve space where men compete as argued by Errington and Gewertz. However, Mead and then Errington and Gewertz rightly demonstrated that men's house drew a demarcation between men's space and another space. However the two opposed spaces - the enclosed realm of men and the open realm surrounding it - are relatively porous and permeable in Chambri. Through initiation and other rituals, Chambri women can access men's secrets. We can also draw some analogies between the partly transparent nature of the men's house (during its construction and its phase of decay) and the metaphor of the string bag high- lighted by Hauser-Schäublin about Abelam ceremonial houses. What is hidden inside the men's house can be partly perceived from the outside. In this way men's realm is not opposed symmetrically to women's realm, but in Chambri both realms are partly permeable.

\section{REFERENCES}

Allen Michael R., 1967. Male Cults and Secret Initiations in Melanesia, Melbourne, Melbourne University Press.

Bateson Gregory, 1980 [1958]. Naven: a survey of the problems suggested by a composite picture of the culture of a New Guinea tribe drawn from three points of view, Stanford, Stanford University Press.

Bowden Ross, 1983. Yena: Art and Ceremony in a Sepik Society, Oxford, Pitt Rivers Museum \& University of Oxford.

CoIfrier Christian, 1994. L'écorce et la moelle du rotin : Tshimbe Kuvu, Kwiya Kuvu, conception iatmul de l'univers, Thèse de doctorat, Paris, eness.

Coupaye Ludovic, 2013. Growing artefacts, Displaying relationship: Yams, Art and Technology amongst the Nyamikum Abelam of Papua New Guinea, New York, Oxford, Berghahn.

ERrington Frederick \& Deborah Gewertz, 1987. Cultural Alternatives and a Feminist Anthropology: An Analysis of Culturally Constructed Gender Interests in Papua New Guinea, Cambridge, Cambridge, University Press.

Falck Christiane, 2016. Calling the Dead Spirits, Mobile Phones and the Talk of God in a Sepik Society, PhD thesis, Aarhus and Cairns, Aarhus University and James Cook University. 
Garnier Nicolas, 2007. Rituels Chambri : analyse de concepts sous-tendant leur vie sociale, East Sepik Province, Papouasie Nouvelle-Guinée, $\mathrm{PhD}$ Thesis, Paris, Muséum national d'histoire naturelle.

-, 2013. Les Christianismes chez les Chambri de Papouasie Nouvelle-Guinée (Province de l'East Sepik), in F. Faberon et J.-Y. Faberon (éds), Religion et société en Nouvelle-Calédonie et en Océanie, Université d'Auvergne, Centre Michel de l'Hôpital, pp. 187-201.

-, 2015. Schönheit und Verwandtschaft, in P. Peltier, M. Schindlbeck et C. Kaufmann (éds), Tanz der Ahnen, Kunst vom Sepik in Papua-Neuguinea, München, Hirmer, pp. 78-87.

Garnier Nicolas (éd.), 2009. Twisting Knowledge and Emotions: Modern Bilums of Papua New Guinea, Port Moresby, Alliance française de Port Moresby.

Gewertz Deborah, 1977. On Whom Depends the Action of the Elements: Debating among the Chambri, Journal of Polynesian Society 86, pp. 339-353.

Gewertz Deborah B. and Frederick Errington, 1991. Twisted Histories, Altered Contexts Representing the Chambri in a World System, Cambridge, Cambridge University Press.

Hauser-SchäUblin Brigitta, 1989. Kulthäuser in Nordneuguinea, Berlin, Akademie-Verlag.

-, 2011. The String Bag of the Tambaran: The fragile loops of concealing and revealing in Abelam culture, in D. Lipset \& P. Roscoe (eds), Echoes of the Tambaran: Masculinity, history and the subject in the work of Donald F. Tuzin, Canberra, Australian National University, pp. 45-71.

Herdt Gilbert H. (ed.), 1982. Rituals of Manhood: Male Initiations in Papua New Guinea, Berkeley, University of California Press.

Herdt Gilbert, 2003. Secrecy and Cultural Reality: Ideologies of the New Guinea Men's House, Ann Arbor, University of Michigan.

Hogbin Ian, 1970. The Island of Menstruating Men: Religion in Wogeo New Guinea, Scranton, Chandler Publishing Company.

Kaufmann Christian, 1972. Das Töpferhandwerk der Kwoma in Nord-Neuguinea: Beiträge zur Systematik primärer Töpfereiverfahren, Basel,
Pharos-Verlag H. Schwabe, Basler Beiträge zur Ethnologie 12.

Mead Margaret, 1934. Tamberans and Tumbuans in New Guinea, Natural History 34 (3), pp. 234-246.

-, 1968 [1935]. Sex and Temperament in three primitive Societies, New York, Dell Publishing Company.

Newton Douglas, 1971. Crocodile and Cassowary: Religious Art of the upper Sepik River, New Guinea, New York, Museum of Primitive Art.

Schefold Reimar, 1966. Versuch einer Stilanalyse der Aufhängehaken vom Mittleren Sepik in Neu-Guinea, Basel, Pharos-Verlag H. Schwabe, Basler Beiträge zur Ethnologie 4.

Schindlbeck Markus, 1980, Sago bei den Sawos (Mittelsepik, Papua New Guinea): Untersuchungen über die Bedeutung von Sago in Wirtschaft, Sozialordnung und Religion, Basel, Ethnologisches Seminar der Universität, Wepf, Basler Beiträge zur Ethnologie 19.

Silverman Eric, 2001. Masculinity, Motherhood, and Mockery: Psychoanalyzing Culture and the Iatmul Naven Rite in New Guinea, Ann Arbor, University of Michigan Press.

Telban Borut, 2009. A Struggle with Spirits: Hierarchy, Rituals and Charismatic Movement in a Sepik Community, in P. J. Stewart and A. Strathern (eds), Religious and Ritual Change: Cosmologies and Histories, Durham, Carolina Academic Press, pp. 133-158.

-, 2013. The Power of Place: Spatio-Temporality of a Melanesian Religious Movement, Anthropological Notebooks XIX/3, pp. 81-100.

Tuzin Donald, 1980. The Voice of the Tambaran: Truth and Illusion in Ilabita Arapesh Religion, Berkeley, University of California Press.

—, 1997. The Cassowary's Revenge: The Life and Death of Masculinity in a New Guinea Society, Chicago and London, The Chicago University Press.

Wassmann Jürg, 2001. The Politics of Religious Secrecy, in A. Rumsey and J. F. Weiner (eds), Emplaced Myth: Space, Narrative, and Knowledge in Aboriginal Australia and Papua New Guinea, Honolulu, University of Hawai i Press, pp. 43-70. 